Фразеологічні одиниці мають велике смислове навантаження, їх вибір безпосередньо залежить від історичного та культурного минулого народу, мовної картини світу нації, символів, які може зрозуміти лише носій мови.

У запропонованому дослідженні фразеологізми аналізуються як самостійні мовні одиниці, що характеризуються відповідними диференційними ознаками. Фразеологічний аналіз систем української та англійської мов засвідчив наявність у них як схожих одиниць, так і національно-самобутніх, специфічних. У роботі доведено, що досконале володіння тією чи іншої мовою не можливе без знання фразеології. Якісний словниковий переклад фразеологічних одиниць залежить від співвідношень між одиницями іноземної мови та мови, що перекладається.

Перспективи подальших досліджень вбачаємо у детальному дослідженні механізмів творення та перекладу фразеологізмів української та англійської мов у різних типах текстів та усному мовленні.

\section{СПИСОК ВИКОРИСТАНОЇ ЛІТЕРАТУРИ}

Сога, Л. (2017). Особливості вживання фразеологічних виразів іноземної мови.Психолінгвістика. Вип. 21 (2). С. 109.

Гарапко, В., Зубрицька, О. (2017). Фразеологізми в англійській мові. Науковий вісник Мукачівського державного університету: журнал наукових праць. №23 (18).

Береза, Т. (2012). Сучасний англо-український словник живої мови. Львів: Апріорі. 400 с.

Зінченко, Г. (2018). Англійські прислів'я та їхні українські відповідники. Київ: Арій. 112 с.

Siefring, J. (2004). Oxford Dictionary of Idioms. Judith Siefring. Oxford: Oxford University Press. 340 p.

Spears, R. (2007). McGraw-Hill's Essential American Idioms Dictionary. New York: The McGraw-Hill Companies, Inc. 276 p.

Зубрик, А. (2013). Особливості та труднощі перекладу англійських фразеологізмів. Наукові записки. Серія “Філологічна”. Острог: Видавництво Націо- нального університету “Острозька академія”. Вип. 36. C. 317.

Ужченко, В., Ужченко, Д. (2007). Фразеологія сучасної української мови: навчальний посібник. Київ: Знання. 497 с.

\section{REFERENCES}

Soha, L. (2017). Osoblyvosti vzhyvannia frazeolohichnykh vyraziv inozemnoi movy [Features of the use of phraseological expressions of a foreign language]. Psykholinhvistyka. Vyp. 21 (2). S. 109. [in Ukrainian].

Harapko, V., Zubrytska, O. (2017). Frazeolohizmy $\mathrm{v}$ anhliiskii movi [Phraseologisms in English]. Naukovyi visnyk Mukachivskoho derzhavnoho universytetu: zhurnal naukovykh prats. №23 (18). [in Ukrainian].

Bereza, T. (2012). Suchasnyi anhlo-ukrainskyi slovnyk zhyvoi movy [Modern English-Ukrainian dictionary of living language]. Lviv: Apriori. 400 s. [in Ukrainian].

Zinchenko, H. (2018). Anhliiski pryslivia ta yikhni ukrainski vidpovidnyky [English proverbs and their Ukrainian equivalents]. Kyiv: Arii. 112 s. [in Ukrainian].

Siefring, J. (2004). Oxford Dictionary of Idioms. Judith Siefring. Oxford: Oxford University Press. 340 p. [in English].

Spears, R. (2007). McGraw-Hills Essential American Idioms Dictionary. New-York: The McGraw-Hill Companies, Inc. 276 p. [in English].

Zubryk, A. (2013). Osoblyvosti ta trudnoshchi perekladu anhliiskykh frazeolohizmiv [Features and difficulties of translation of English phraseology]. Naukovi zapysky. Seriia "Filolohichna". Ostroh: Vydavnytstvo Natsionalnoho universytetu "Ostrozka akademiia". Vyp. 36. S. 317. [in Ukrainian].

Uzhchenko, V., Uzhchenko, D. (2007). Frazeolohiia suchasnoi ukrainskoi movy [Phraseology of the modern Ukrainian language]: navchalnyi posibnyk. Kyiv: Znannia. 497 s. [in Ukrainian].

Дата надходження до редакиії: 27.11.2020 p.

\section{Лілія ОВДІйчУк,}

кандидат педагогічних наук, дочент, докторант кафедри українськоӥ

і зарубіжної літератури та методик викладання Університету Григорія Сковороди у Переяславі,

м. Переяслав, Україна

ORCID: 0000-0002-0268-5969

e-mail:liliaregi@ukr.net

\title{
ЛІТЕРАТУРНЕ КРАЄЗНАВСТВО У ФАХОВІЙ ПІДГОТОВЦІ МАЙБУТНІХ УЧИТЕЛІВ УКРАЇНСЬКОЇ МОВИ ТА ЛІТЕРАТУРИ: ІНТЕГРАЦІЙНИЙ АСПЕКТ
}

\begin{abstract}
Анотація. У статті йдеться про літературне краєзнавство як складову історико-літературних дисииплін. Дослідниия розкриває особливості інтеграційного вивчення літературного краєзнавства у прочесі підготовки майбутніх учителів украӥнськоі мови і літератури, визначає принципи, методи та
\end{abstract}

засоби інтеграції у процесі вивчення авторського курсу «Літературне краєзнавство».

У статті репрезентовано авторські літературно-краєзнавчі дослідження: післямови та передмови до перевидань раритетних книг, статті про творчість рівненських письменників за персоналіями. 
Ïх систематизовано й запропоновано як авторський спецкурс для студентів спеціальності «Українська мова та література» й уведено до навчального плану бакалаврів 2020 року вступу.

Вивчення тематичних блоків («Книговидавнича діяльність рівненської «Просвіти»: краєзнавчий аспект», «Жанрово-стильові різновиди прози письменників Рівненщини. Драматургія», «Олександр Купрін і Рівненське Полісся》, «Поетична Рівненщчина») відбувається із застосуванням міждисииплінарної інтеграчії через змістовий (внутрішньо- $i$ зовнішньопредметний) та діяльнісний аспекти. Основну увагу зосереджено на різних формах ознайомлення студентів із літературно-краєзнавчими матеріалами.

Доведено, шчо у процесі такого освоєння літературно-краєзнавчого матеріалу у студентів формується інтеграційно-літературознавча компетентність.

Ключові слова: майбутні вчителі украӥнської мови та літератури, літературне краєзнавство, авторський спецкурс «Літературне краєзнавство Рівненшини», міждисииплінарна інтеграчія, діяльнісна інтеграчія, інтеграція навчальної та науково-дослідницької діяльності, інтеграційно-літературознавча компетентність.

\section{Lilia OVDIICHUK,}

Ph.D. in Pedagogy, Associate Professor, Associate Professor of Pedagogy Department of Ukrainian and Foreign Literarure and Methods Hryhorii Skovoroda University in Pereiaslav,

Pereiaslav, Ukraine

ORCID: 0000-0002-0268-5969

e-mail: liliaregi@ukr.net

\section{LITERARY LOCAL HISTORY IN THE PROFESSIONAL TRAINING OF FUTURE TEACHERS OF THE UKRAINIAN LANGUAGE AND LITERATURE: INTEGRATION ASPECT}

\begin{abstract}
The article deals with literary country studies as an integral part of historical and literary disciplines. The importance of its study is specified by the existence of a whole layer of literary texts that remain on the margins of the all-Ukrainian literary process, but have significant artistic and aesthetic value, historical and cultural significance for experts, teachers of Literature and for all who are interested in fine writing.

The researcher reveals the features of the integration learning of literary country studies in the process of training of future teachers of Ukrainian Language and Literature, determines the principles, methods and means of integration in the process of studying the author's course "Literary country studies».

The article presents the author's literary and country studying researches: epilogues and prefaces to reprints of rare books, articles about the work of Rivne writers. They were systematized and presented as an author's special course for students majoring in Ukrainian Language and Literature and introduced into the curriculum of bachelors in 2020.

Study of such thematic blocks as "Book publishing activity of Rivne's Prosvita: country study aspect», "Genre and style varieties of prose of Rivne region writers. Dramaturgy», "Olexandr Kuprin and Rivne's Polissya», "Poetic Rivne Region» is carried out with the use of interdisciplinary integration through semantic (internal and external subject) and activity aspects. The content aspect is provided through connections with the history and culture of the native land, folk art, activity - through the integration of educational and research activities of students. The article reveals various forms of acquaintance with literary and country studies materials: book presentations, regional conferences, round tables, meetings with writers, excursions to museums.
\end{abstract}

It is proved that in the mastering process of literary and country studying material students form integration and literary competence, which is revealed in their creative works: essays, reviews, posts on the faculty website, Facebook and other social networks. The subject of future scientific studies may be personalities and genre-style varieties of artistic texts of Rivne region.

Key words: Future teachers of Ukrainian Language and Literature, literary country studies, author's special course "Literary country studies of Rivne region», interdisciplinary integration, activity integration, integration and literary competence.

Постановка проблеми. Літературне краєзнавство $\epsilon$ складовою частиною історико-літературних дисциплін. Важливість його вивчення обумовлена існуванням цілого пласту художніх текстів, які залишаються на маргінесах всеукраїнського літературного процесу, проте мають значну художньо-естетичну цінність, історичне та культурне значення для фахівців, учителів української та зарубіжної літератури, краян і для всіх, хто цікавиться красним письменством.

«В останні роки наша держава стоїть перед завданням презентації власного історико-культурного надбання перед європейською та світовою спільнотою. А це можливо не лише за умови проведення узагальнюючих інтегративних досліджень літературного процесу України в цілому, але й за умов глибокого, системного вивчення літератури кожного окремого регіону нашої держави» (Лисенко, 2000, с. 3).

У реаліях сьогодення у закладах вищої освіти необхідне впровадження інноваційних засобів, форм, методів навчання, які враховують інтеграційну складову. Зокрема, це стосується й викладання літературного краєзнавства як навчального курсу. 
Аналіз наукових досліджень і публікацій. Українські вчені, зокрема С. Гончаренко, Ю. Жидецький, М. Іванчук, С. Клепко, Я. Кміт, І. Козловська, О. Комар, Р. Мустафіна, В. Нічишина, О. Сергеєв, В. Сидоренко, Я. Собко, Ю. Стиркіна, М. Чепіков, Л. Шаповалова, В. Якиляшек, Т. Якимович, відстоюють формування системи предметно-інтегративного навчання, тобто взаємодоповнення процесів інтеграції та диференціації. Така дидактична система не відкидала б «диференціацію в навчанні, а доповнювала іiі на основі інтеграції, що більшою мірою ніж традиційне попредметне навчання сприяло б вихованню широко ерудованої молодої людини, якій притаманний цілісний світогляд, здатність самостійно систематизувати наявні знання i нетрадиційно підходити до вирішення різних проблем.

Такий спосіб розгортання інтеграції не ламає традиційний набір навчальних дисциплін, дає можливість подолати наслідки їх ізольованого вивчення та більшу ймовірність досягнення високого рівня якості знань студентів» (Нічишина, 2014, с. 181).

Можливості інтеграції навчальних дисциплін на літературознавчій основі частково розглядалися Н. Романишиною, О. Куцевол, яка певною мірою розкрила аспект поєднання інноваційних форм і методів навчальної діяльності студентів 3 уже традиційними і достатньо апробованими формами і методами викладання у вищій школі, наприклад, інтегративна лекція (лекція удвох). Л. Базиль порушувала це питання у контексті формування літературознавчої компетентності майбутніх учителів української мови та літератури.

Літературне краєзнавство, його теорія та історія були і предметом уваги літературознавців, педагогів та істориків. Етапи розвитку літературно-краєзнавчих досліджень розкрив М. Волинець: від «започаткування літературного краєзнавства, у процесі якого відбулося становлення краєзнавства як науки», до «удосконалення літературно-краєзнавчої роботи в системі загальної середньої, вищої, післядипломної освіти, а також у культурно-історичній діяльності суспільства» (Волинець). Наукові основи вивчення літературного краєзнавства в школі досліджували Є. Пасічник, О. Фесенко, М. Янко. У контексті професійної освіти цю проблему розглядали Т. Міщенко, А. Лисенко. Г. Самойленко у монографії «Краєзнавство культурно-мистецьке та літературне» обгрунтував наукові основи викладання цього предмета у закладах вищої освіти.

Проте спеціального дослідження щодо інтеграційного аспекту вивчення літературного краєзнавства у фаховій освіті бакалаврів спеціальності 014 «Середня освіта (Українська мова і література)» не було.

Мета статті - розкрити особливості інтеграційного вивчення літературного краєзнавства у процесі підготовки майбутніх учителів української мови і літератури.

Виклад основного матеріалу дослідження. Система літературознавчої підготовки студентів передбачає включення до навчальних планів історико-літературних («Історія української літератури», «Історія зарубіжної літератури»), теоретико-літературних курсів, а також дисциплін «Фольклор» та «Дитяча література». Кожен із цих навчальних предметів має краєзнавчий аспект, тому важливо передбачати теми з літературного краєзнавства на кожному етапі вивчення історії української та історії зарубіжної літератури, а також регіональних фольклорних та художніх текстів, адресованих дітям.
Оскільки авторка статті тривалий час досліджувала літературу Рівненського регіону, була автором передмов та післямов до раритетних книг, які перевидала Рівненська міська організація «Просвіта», виникла необхідність систематизувати зібраний матеріал. Тематично виокремлено книговидавничу діяльність Рівненської «Просвіти» (краєзнавчий аспект), зокрема, це:

- «Рівне у долі Юрія Горліса-Горського» (Овдійчук Л. «Холодні яри життя Ю. Горліса-Горського» (Слово про автора). Післямова) (Овдійчук, 2000);

- «Тексти долі: Рівненський період життя і творчості Зузанни Гінчанки та Олени Теліги» (Овдійчук Л. «Зузанна Гінчанка та Олена Теліга: біографічні паралелі яскравих особистостей») (Овдійчук, 2018).

Другу важливу тему «Олександр Купрін і Рівненське Полісся» репрезентовано такими дослідженнями:

«Поліськими стежками О. Купріна: біографічні епізоди» (Овдійчук Л. «Чаклунка 3 поліських лісів». Післямова) (Овдійчук, 2005);

«Повість «Олеся» О. Купріна українською мовою: історія створення» (Овдійчук, 2005);

«Твори, на які надихнуло Полісся» (Овдійчук Л. «Поліський цикл творів Олександра Купріна») (Овдійчук, 2010);

Тема «Поетична Рівненщина» розкривається через такі аспекти:

- Лірика і традиції (Овдійчук Л. «Словом змалювати стан душі...» Передмова. (Овдійчук, 2012);

- Творчі пошуки поетів-сучасників Рівненщини: від немодерну до постмодерну (Анна Лимич, Неоніла Диб'як, Юлія Бондючна, Наталя Демедюк, Валентина Люлич, Тата Рівна, Ірина Баковецька).

Тема «Жанрово-стильові різновиди прози письменників Рівненщини. Драматургія» представлена такими напрямами:

- Історична проза: тематика, стиль, жанри (П. Кралюк, Є. Шморгун, Б. Боровець, С Праск);

- Реалістична проза (Л. Рибенко, Б. Боровець, А. Кондратюк, В. Мазаний, С. Гридін);

- Фантастика: жанрові модифікації (Л. Рибенко, Є. Шморгун);

- Поетика прози постмодерну (О. Ірванець, I. Баковецька, О Єфіменко, П. Кралюк);

- Драматургія: від витоків до сучасності (У. Самчук, О. Ірванець, О. Заворотній) (Овдійчук Л. «У калейдоскопі людських доль» (за п'єсами Олексія Заворотнього). Післямова) (Овдійчук, 2011).

До теми «Фольклор та дитяча література» запропоновано дві підтеми: «Усна народно-поетична творчість Рівненщини» та «Жанрово-тематичне багатство літератури рідного краю для дітей».

Тему «Літературознавство Рівненщчини. Періодика. Альманахи. Щорічний обласний конкурс «Краща книга Рівненщини». Видавництвво "Азалія» розкрито завдяки таким аспектам:

- Літературознавчі дослідження та дослідники-краєзнавці Рівненщини (Б. Боровець, Г. Дем'янчук, В. Мазаний, Я. Поліщук, І. Захарчук, Є. Шморгун та ін.);

- Літературно-мистецький часопис «Погорина»: рубрикація, жанри, тематика: $з$ досвіду співпраці;

- Обласний конкурс «Краща книга Рівненщини»: здобутки і відкриття (із досвіду члена журі з 2009-2020 років); 
- Видавництво Рівненської спілки письменників «Азалія»: досягнення і перспективи.

У навчальний план бакалаврів спеціальності «Українська мова і література» Міжнародного економіко-гуманітарного університету імені академіка Степана Дем'янчука (2020 року вступу) включено авторський спецкурс «Літературне краєзнавство Рівненщини», до якого ввійшли означені теми.

Інтеграція, з філософської точки зору С. Ф. Клепка, концептуально постає як механізм самоорганізації хаосу знань, як внесення порядку, єдності в розчленований світ знань із метою підвищення ефективності як здобуття, так і застосування знання (Клепко, 1998, с. 14).

У професійній освіті ефективним є застосування змістового (внутрішньо- і зовнішньопредметного) та діяльнісного аспектів інтеграції. Змістовий аспект забезпечується через зв'язки з історією та культурою рідного краю, народною творчістю. Діапазон таких знань охоплює період від середньовіччя до сучасності. Майбутні вчителі української мови та літератури отримують нову інформацію, актуалізують знання з «Історії та культури України», частиною якої є регіональний історикокультурний пласт. Важливим підгрунтям для успішного вивчення літературно-краєзнавчих тем є створення відповідного навчального середовища: підбір матеріалу для занять, форма проведення (різновиди лекцій, практичних; аудиторні, позааудиторні), а також технології, методи і прийоми (традиційні, інноваційні). Майбутні вчителі української мови та літератури відкривають для себе нові імена, важливі здобутки місцевих авторів у багатьох літературних жанрах (роман-антиутопія (О. Ірванець), роман-мозаїка (Б. Боровець), детективний роман з елементами психологізму (І. Баковецька-Рачковська), поезопроза (Тата Рівна) та ін.

«Дух» історичної доби можна відтворити за допомогою інтегрованих знань з історії та культурології. 3 досвіду викладання авторки у ЗВО ефективним засобом актуалізації різнорідних знань є графічний систематизатор у вигляді універсальної синхронної таблиці-матриці з такими складниками: суспільно-політичні події, наукові досягнення, культурно-мистецькі здобутки, художня література. До цієї таблиці варто звертатися не тільки у процесі вивчення монографічних тем з історії української та зарубіжної літератури, а й під час опрацювання літературно-краєзнавчого матеріалу. У цьому випадку відбувається корекція уже на рівні регіональному: які 3 подій безпосередньо пов'язані з рідним краєм. Наприклад, нинішня Рівненська область у XVI столітті перебувала у складі Речі Посполитої, проте рід князів Острозьких міцно утримував оплот православ'я на своїй спадковій землі. Тому наука, культура, освіта в регіоні має значні здобутки саме завдяки цій династії і про них варто нагадати студентам. До уже відомих подій і фактів додаються більш конкретніші. Для прикладу, інший історичний період: Рівненщина під час Другої світової війни перебувала в епіцентрі боротьби різних сил: гітлерівської та радянської армій, УПА, Армії Крайової та партизанських з'єднань. Рівне було центром рейхскомісаріату, що відобразилося на провінційному тоді містечку. Отже, відоме доповнюємо невідомим. Для цього організовуємо відвідування краєзнавчого музею, Острозького замку, де студенти-філологи послухають детальні розповіді екскурсоводів про події тих років.
Таким чином, формується підгрунтя для сприйняття історичних творів (П. Кралюк «Шестиднев, або Корона дому Острозького», Б. Боровець «Заглада», С. Праск «Здобути або не бути», «Сотенний Лис»). Інтеграція навчальних та позааудиторних занять створює умови для особистісного розвитку, розширення кола інтересів, світогляду майбутніх словесників.

Студенти спеціальності «Українська мова та література» ознайомлюються 3 матеріалами краєзнавчих досліджень на конференціях, презентаціях книг, зустрічах із письменниками. Це мотивує до вивчення літератури рідного краю у різних площинах: навчальній та дослідницькій, реалізуючи таким чином один із пріоритетних напрямів реформування вищої освіти: інтеграцію освітньої і наукової складової (Біла книга національної освіти України, 2011, с. 256). Основне завдання інтеграції навчальної та науково-дослідницької діяльності студентів полягає у використанні краєзнавчих досліджень як інформаційного матеріалу на лекціях, практичних заняттях, під час виконання індивідуальних завдань та у поетапній трансформації навчальної у навчально-дослідницьку, а згодом у науково-дослідницьку. Авторка статті досліджувала тексти класичні, а також різнотематичні й різножанрові твори місцевих авторів, які були предметом вивчення на лекційних та практичних заняттях. Окрім змісту звертається увага на форму дослідження, оскільки це були передмови та післямови до раритетних книг, а також наукові, науково-популярні та науково-навчальні статті. Таким чином, студенти мають можливість на практиці ознайомлюватися з методикою написання різножанрових наукових праць. Студенти I-II курсів ознайомлюються вперше з такою діяльністю, у той час як студенти III-IV курсів використовують та удосконалюють свої знання з курсу «Основи наукових досліджень». Внутрішньопредметна інтеграція відбувається під час аналізу художніх творів у єдності змісту і форми, оскільки актуалізуються й формуються нові знання з теоретико-літературних курсів «Вступ до літературознавства» та «Теорія літератури».

Студентам пропонується широкий вибір тем із літературного краєзнавства для рефератів, курсових та кваліфікаційних робіт. Наприклад, із курсу «Дитяча література» пропонуються теми: «Література класичного канону для дітей: краєзнавчий аспект (О. Купрін, В. Короленко)», «Жанрово-тематична палітра літератури Рівненщини для дітей у XX столітті», «Сучасна дитяча література Рівненщини: жанрово-тематичне розмаїття», «Сучасна українська дитяча література кінця XX початку XXI ст.: тематика, стилі, жанри». 3 «Історії української літератури» запропонована тематика стосується жанрово-стильових особливостей історичної та реалістичної прози, окремих персоналій (Уласа Самчука, Андрія Кондратюка, Петра Кралюка, Сергія Гридіна), з «Історії зарубіжної літератури» творчості Олександра Купріна, Володимира Короленка, Зузанни Гінчанки, Ігнація-Юзефа Крашевського.

Культурологічна складова літературно-краєзнавчих тем, які пропонуються для вивчення, торкається діяльності громадської організації «Просвіта», 100-річчя від дня заснування якої широко відзначали у 2017 році на Рівненщині. Авторка цього дослідження $є$ членом ради міської організації «Просвіта», бере участь у проєкті з перевидання раритетних книг як 
літературознавець. Втретє відроджена громадська організація робить чимало для утвердження української літератури та культури, зокрема повертає в літературний процес художні твори, які мають історичну й естетичну цінність.

Презентації таких книг відбувалися в Міжнародному університеті імені академіка Степана Дем'янчука, в Обласній науковій універсальній бібліотеці, Обласній бібліотеці для молоді. Співпраця з бібліотеками - це ще один вид інтеграції, оскільки такого масштабу книгозбірні мають багатий фонд: персональні бібліотеки відомих людей, передані на збереження і користування, іноземні та діаспорні видання, книги сучасних авторів, краєзнавчу літературу. У зв'язку з цим перебування в бібліотеці не обмежується конкретним спільним заходом. Першокурсникам, які вперше відвідують заклад, проводять змістовну екскурсію, знайомлять із відділами (краєзнавчим, мистецьким, відділом абонемента, читальним залом, «Світлицею», залом для користування інтернетом, книгосховищем тощо). У приміщенні бібліотеки відбуваються лекції з історико-літературних курсів, насамперед ті, що тематично пов'язані з літературою рідного краю, оскільки у краєзнавчому відділі сконцентровано необхідний матеріал, функціонують книжкові виставки. Окрім того, майбутні словесники мають змогу користуватися фондами бібліотеки під час підготовки до практичних занять чи виконуючи індивідуальне дослідницьке завдання.

Важливість таких заходів для майбутніх учителів української мови та літератури очевидна. Під час їх проведення здійснюється комплексний вплив на реципієнтів, на їхню інтелектуальну, діяльнісно-вольову та емоційно-ціннісну сферу. Майбутні словесники отримують нові знання не тільки з регіональної історії літератури, а й з історії та фольклору рідного краю. Вони відкривають для себе нові імена, важливі здобутки місцевих авторів у багатьох літературних жанрах та стилях. Презентації книг, як правило, супроводжуються виступами місцевих творчих фольклорних колективів, які репрезентують пісенну лірику поліського краю. Запрошені актори Рівненського музично-драматичного театру читають уривки із презентованих творів (О. Заворотній, Г. Цьомик), артисти Обласної філармонії (Г. Швидків, М. Швидків) виконують покладені на музику літературні тексти місцевих авторів, В. Люлич, поетка-бард, співає власні твори, акомпануючи на гітарі. Такий спектр взаємодії чинить різнобічний вплив на особистість: когнітивний, мотиваційно-ціннісний, естетичний. 3 огляду на поєднання всіх частин навчального та позанавчального процесів, коли задіюються різноманітні чинники для освоєння літературно-краєзнавчого матеріалу, коли у сприйнятті бере участь емоційно-вольова сфера, у студентів формується інтеграційно-літературознавча компетентність. Насамперед це виявляється у творчих роботах краєзнавчого характеру: есе, рецензіях, відгуках, дописах на сайті факультету, у фейсбуці та інші соціальних мережах. У таких текстах поєднане критичне осмислення інформації, емоційна оцінка, оригінальні думки, естетичні враження.

Висновки. На основі проведеного дослідження можна зробити висновок, що Рівненщина багата літературними талантами, культурними традиціями, які необхідно впроваджувати у навчальний процес закладів вищої освіти через уведення спецкурсу або шляхом викладання краєзнавчого матеріалу в курсі історії літератури (української та зарубіжної) відповідно до конкретної історико-літературної доби. Внаслідок застосування міждисциплінарної (внутрішньої та зовнішньої) інтеграції, а також інтеграції навчальної та позанавчальної, навчальної та науково-дослідницької діяльності у майбутніх учителів української мови та літератури формується інтеграційно-літературознавча компетентність.

Перспективи подальших досліджень. Обсяг цієї статті не дозволяє розкрити всі аспекти інтеграційного вивчення літературного краєзнавства, тому предметом наукових студій можуть бути персоналії та жанрово-стильові різновиди художніх текстів Рівненського регіону.

\section{СПИСОК ВИКОРИСТАНОЇ ЛІТЕРАТУРИ}

Лисенко, А. В. (2002). Методика використання літературного краєзнавства в системі підвищення кваліфікації вчителів-словесників: автореф. дис. ... канд. пед. наук: спец. 13.00.02. Київ. 26 с.

Нічишина, В. В. (2014). Про науково-теоретичні засади підвищення ефективності професійної підготовки майбутніх учителів на основі інтегративного підходу. Наукові записки. Серія «Педагогічні науки». Кіровоград. №134. С.178-182.

Волинець, М. Теорія та історія літературного краєзнавства. URL: https://www.narodnaosvita.kiev.ua/ Narodna_osvita/vupysku/8/statti/2volinec.htm (дата звернення: 11.11.2019).

Овдійчук, Л. М. (2000). Холодні яри життя Ю. Горліса-Горського (Слово про автора). Післямова до книги Ю. Горліса-Горського "Ave dictator». Рівне. C. $19-22$.

Овдійчук, Л. М. (2018). Зузанна Гінчанка та Олена Теліга: біографічні паралелі яскравих особистостей. Dialog dwóch kultur (Діалог двох культур). Варшава. C. 221-226.

Овдійчук, Л. М. (2005). Чаклунка з поліських лісів. Післямова. Купрін О. Олеся: повість. Рівне: Волинські обереги. С. 106-121.

Овдійчук, Л. М. (2010). Поліський цикл творів Олександра Купріна. Погорина. №14-15. С. 243-248.

Овдійчук, Л. М. (2012). Словом змалювати стан душі... Передмова до поетичної збірки Н. Дворницької «Промінь осяяння. Поезї̈». Рівне. С. 3-6.

Овдійчук, Л. М. (2011). У калейдоскопі людських доль (за п'єсами Олексія Заворотнього). П'єси. Рівне. C. 498-502.

Клепко, С. Ф. (1998). Інтегративна освіта і поліморфізм знання. Київ; Полтава; Харків: ПОІПОПП. $360 \mathrm{c}$.

Алексєєнко, Т. Ф., Аніщенко, В. М., Балл, Г. О. (2011). Біла книга національної освіти України / за заг. ред. акад. В. Г. Кременя; НАПН України. 3-є вид. Київ: Київський ун-т ім. Бориса Грінченка. 342 с.

\section{REFERENCES}

Lysenko, A. V. (2002). Metodyka vykorystannja literaturnogho krajeznavstva v systemi pidvyshhennja kvalifikaciji vchyteliv-slovesnykiv [The Methodology of the 
local literature Study Usage in the Qualification Improvement of the Teacher]: avtoref. dys. ... kand. ped. nauk: spec. 13.00.02. Kyiv. 26 s. [in Ukrainian].

Nichyshyna, V. V. (2014). Pro naukovo-teoretychni zasady pidvyshhennja efektyvnosti profesijnoji pidghotovky majbutnikh uchyteliv na osnovi integhratyvnogho pidkho$\mathrm{du}$ [About scientific and theoretical foundations of efficiency increase of professional training of future teachers on the basis of the integrative approach]. Naukovi zapysky. Seriya «Pedagogichni Nauky». Kirovoghrad. №134. S.178-182. [in Ukrainian].

Volynecj, M. Teorija ta istorija literaturnogho krajeznavstva [The theory and history of literary study of local lore]. URL: https://www.narodnaosvita.kiev.ua/Narodna_osvita/vupys$\mathrm{ku} / 8 /$ statti/2volinec.htm (data zvernennja: 25.01 .2021 ). [in Ukrainian].

Ovdijchuk, L. M. (2000). Kholodni jary zhyttja Ju. Ghorlisa-Ghorsjkogho (Slovo pro avtora) [Cold Stages of Yu. Horlis-Horskyi Life (Words about the author)]. Pisljamova. Ju. Ghorlis-Ghorsjkyj “Ave distator”. Rivne. S.19-22. [in Ukrainian].

Ovdijchuk, L. M. (2018). Zuzanna Ghinchanka ta Olena Teligha: bioghrafichni paraleli jaskravykh osobystostej [Zuzanna Ginchanka and Olena Teliha: Biographical Parallels of Extraordinary Personalities]. Dialog dwóch kultur. Varshava. S. 221-226. [in Poland].
Ovdijchuk, L. M. (2005). Chaklunka z polisjkykh lisiv. Pisljamova. [The Sorceress from Polissia Forests]. Kuprin O. Olesja: povistj. Rivne: Volynsjki obereghy. S. 106-121. [in Ukrainian].

Ovdijchuk, L. M. (2010). Polisjkyj cykl tvoriv Oleksandra Kuprina [Polissia Cycle of Oleksandr Kuprin's Works]. Poghoryna. №14-15. S. 243-248. [in Ukrainian].

Ovdijchuk, L. M. (2012). Slovom zmaljuvaty stan dushi... [In a word to describe the state of mind...]. Peredmova do poetychnoi zbirky Dvornycjka N. Prominj osjajannja. Poeziji. Rivne. S. 3-6. [in Ukrainian].

Ovdijchuk, L. M. (2011). U kalejdoskopi ljudsjkykh dolj (za p'jesamy Oleksija Zavorotnjogho) [In Kaleidoscopes of People's Fates (after plays of Oleksii Zavorotnii)]. P'jesy. Rivne. S.498-502. [in Ukrainian].

Klepko, S. F. (1998). Integhratyvna osvita i polimorfizm znannja [Interactive Education and Multiformity of Knowledge]. Kyjiv; Poltava; Kharkiv: POIPOPP. 360 s. [in Ukrainian].

Aleksjejenko, T. F., Anishhenko, V. M., Ball, Gh. O. ta in. (2011). Bila knygha nacionaljnoji osvity Ukrajiny [The White Paper of National Education of Ukraine] / za zagh. red. akad. V. Gh. Kremenja; NAPN Ukrajiny. 3-je vyd. Kyiv: Kyivsjk. un-t im. Borysa Ghrinchenka. 342 s. [in Ukrainian].

Дата надходження до редакиї: 26.01.2021 p. 